\title{
A kiégés előfordulása és megelőzési lehetőségei ápolók körében
}

\author{
Czeglédi Edit dr. ${ }^{1}$ - Tandari-Kovács Mariann dr. ${ }^{2}$ \\ ${ }^{1}$ Semmelweis Egyetem, Általános Orvostudományi Kar, Magatartástudományi Intézet, Budapest \\ ${ }^{2}$ Gál Ferenc Főiskola, Szeged
}

\begin{abstract}
Az egészségügyi ellátórendszeren belül az ápolói pályán dolgozók fokozottan veszélyeztetettek a kiégési szindróma (érzelmi kimerültség, elszemélytelenedés, a személyes hatékonyság és a teljesítmény csökkenése) kialakulása szempontjából. A kiégés nemcsak az egyénre nézve bír kedvezőtlen egészségi és gazdasági következményekkel, hanem rontja a kezelési együttmúködést és az ellátás minőségét, illetve befolyásolja a múhibák és a szövődmények előfordulási gyakoriságát is. Éppen ezért a kiégési szindróma felismerése, megelőzése és kezelése össztársadalmi érdekünk. A tanulmányban bemutatjuk a kiégés előfordulási gyakoriságát a hazánkban dolgozó ápolók körében, valamint a kiégés prevenciójának lehetséges színtereit és módjait, különös tekintettel a pszichológiai tanácsadás szerepére, illetve lehetőségeire. Mindez gyakorlati szempontú hozadékkal járhat a kiégés megelőzéséért folytatott küzdelemben. Orv Hetil. 2019; 160(1): 12-19.
\end{abstract}

Kulcsszavak: kiégés, kiégési szindróma, ápoló, megelőzés, pszichológus

\section{Characteristics and prevention of burnout syndrome among nurses}

Within the health care system, nurses face multiple hazards from the aspect of burnout syndrome (emotional exhaustion, depersonalisation, and reduced personal accomplishment) development. Burnout has a negative impact on the health and economic status of individuals. Moreover, burnout diminishes compliance, reduces the quality of care, and it influences the prevalence of medical malpractice and complications. Therefore the identification, prevention and treatment of burnout are of public interest. In this study, we present the occurrence of burnout among Hungarian nurses, and we recommend options to prevent the burnout of nurses, focusing especially on the role and possibilities of psychological counselling. All these provide practical aspects and feasibility in preventing and overcoming burnout.

Keywords: burnout, burnout syndrome, nurse, prevention, psychologist

Czeglédi E., Tandari-Kovács M. [Characteristics and prevention of burnout syndrome among nurses]. Orv Hetil. $2019 ; 160(1): 12-19$.

(Beérkezett: 2017. július 17.; elfogadva: 2018. augusztus 4.)

A kiégési szindróma globális jelenség, a nemzetközi és a hazai szakirodalomban egyaránt sokat tárgyalt és kutatott tünetcsoport [1-3]. A globalizáció, a privatizáció és a liberalizáció gyors változásokat eredményezett a modern munkakörnyezetben. Számos új készség elsajátítására van szükség, egyre nagyobb időnyomás mellett magas teljesítményelvárásoknak kell megfelelni [2]. Mindezt megnehezíti, hogy az egészségügyi ellátórendszerben dolgozók folyamatos érzelmi igénybevételnek vannak kitéve a páciensekkel és az azok hozzátartozóival való erős emocionális töltetű kapcsolat fenntartása miatt [4].

A kiégés fogalmának meghatározására több törekvés irányult $[1,2]$. A téma kutatásának egyik legelismertebb képviselője, Christina Maslach [5] szerint a kiégés az érzelmi kimerülés, a személytelen bánásmód, valamint a személyes hatékonyság csökkenése mentén leírható tünetcsoport. A kiégés az egész személyiséget érinti. Az érintett személy testi (például krónikus fáradtság, alvászavar, fájdalomérzés), érzelmi (például emocionális kimerültség, reménytelenségérzés, negatív önértékelés, krónikus szorongás, depresszió), viselkedéses/magatartási (például ingerlékenység, cinizmus, koffein-, nikotin-, alkohol-, gyógyszer- és drogfüggőség, evészavarok), valamint mentális tüneteket (például figyelemzavar, a teljesítőképesség csökkenése, beszűkültség, a szakmai inkompetencia érzése) egyaránt megfigyelhet. Az utóbbi 
évtizedben a pozitív pszichológia térnyerésének köszönhetôen fordulat állt be a kiégésről való gondolkodásban: napjainkban a kiégést inkább a munka iránti elkötelezettség eróziójaként emlegetik [2], ráirányítva ezzel a figyelmet a humánerőforrás menedzselésének fontosságára, amely a prevenció és az intervenció szempontjából egyaránt új hangsúlyokat jelent.

Az egészségügyi ellátórendszer területén belül az ápolói pálya halmozottan kockázatosnak tekinthető a kiégés szempontjából [6]. A jelen tanulmány célja a kiégési szindróma előfordulási gyakoriságának bemutatása a hazánkban dolgozó ápolók körében és a pszichológiai tanácsadás szerepének, illetve lehetőségeinek felvillantása az ápolók kiégésének prevenciójában.

\section{$\mathrm{Az}$ ápolókat érintő kiégési szindróma kialakulásában szerepet játszó tényezők}

A kiégési szindróma lassan, évek alatt, ciklikus ismétlődésekkel fejlődik ki $[7,8]$. Etiológiájában a stressz kiemelt szerepü. Az egészségügy szférájában az ápolók tevékenysége az egyik legmagasabb stressz-szinttel jellemezhetó munkakör, amelyben az ápolási tevékenység fizikai jellegzetességeitől kezdve a pszichoszociális stresszhatásokon át a szerepkonfliktusokig bezárólag számos stresszforrás megjelenik $[9,10]$. Egy hazai vizsgálat eredményei szerint [11] az összesített ápolói stresszskála alapján a válaszadók 15,7\%-ának magas, 65,6\%-ának közepes volt a stresszterheltsége, és kevesebb mint egyötödük (18,2\%) stresszterheltsége tartozott a saját megítélésük alapján az alacsony kategóriába. Az ápolók naponta találkoznak érzelmileg megterhelő helyzetekkel, kiszolgáltatott, beteg emberekkel, és e találkozások számtalan érzelmet válthatnak ki [12], amelyek további terheket rónak rájuk. A „mindent megtettünk” szakmai attitűddel együtt járó felelősség tovább növelheti az átélt stresszt, fokozva a kiégés megjelenésének kockázatát $[4,13]$.

A stresszforrásokat érdemes különböző szinteken áttekinteni $[4,8,14]$. Az egyén szintjén találhatók például a munka beleszövődése a magánéletbe, illetve a szerepkonfliktusok. A hivatás szintjén megjelenő stresszforrásokra példa a túlterheltség; a diagnózissal és a kezeléssel kapcsolatos bizonytalanságok; a sürgősségi helyzetek; a szembesülés a betegek és a hozzátartozók kríziseivel, a halállal, illetve a haldoklókkal és a gyászolókkal; valamint az agresszív, illetve a pszichiátriai betegekkel való kapcsolat; a hibátlan teljesítményre vonatkozó elvárás. A munkabely szintjén megjelenő stresszforrásokra példa az egyenlőtlen terhelés; az anyag-, illetve eszközhiány; az autonómia korlátozottsága, illetve a munka tervezésében való szabadság hiánya; a döntéshozatalból való kizárás [15]; a teljesíthetetlennek tûnő feladatok; az adminisztrációs terhek, a páciensektől, illetve a hozzátartozóiktól érkező agresszív megnyilvánulások [16], valamint a csoporton belüli rossz kommunikáció. A munkavégzés időtartama és a munkabeosztás jellege ugyancsak igen megterhelő a szervezet számára, különösen a cirkadián ritmus felborulása miatt. A társadalmi stresszforrások közül a kellő megbecsülés és elismerés hiányát tartjuk lényegesnek kiemelni [7]. Egy hazai vizsgálat eredményei szerint az ápolók 93\%-a érzi úgy, hogy munkájukat nem becsülik meg megfelelően [17]. Az egészségpolitikai stresszforrások közül a pénzügyi nehézségek terhelik az ápolókat a leginkább.

\section{Az ápolók kiégésének előfordulási gyakorisága hazánkban}

Az alábbiakban a teljesség igénye nélkül bemutatunk néhány, az ápolók kiégésének felmérésére irányuló keresztmetszeti, kérdőíves kutatást.

Irinyi és mtsai [16] vizsgálatában szakdolgozók vettek részt, az ország teljes területéről $(n=1201)$. Eredményeik szerint a válaszadók 44,2\%-a volt érintett a kiégés által. Az érintettek egyik felénél (a teljes minta 22,9\%ánál) még csak megjelentek a kiégés egyes tünetei, a másik fele (a teljes minta $21,3 \%$-a) azonban kiégettnek volt tekinthető.

Kovács és Hegedüs [18] vizsgálatában nővérek és aszszisztensek vettek részt az ország különböző részeiről $(\mathrm{n}=76)$. A kiégés egyes dimenziói közül az érzelmi kimerülés a válaszadók 40,6\%-ánál magas, 31,9\%-ánál pedig közepes mértékű volt. A deperszonalizáció magas foka a válaszadók 10,1\%-át, közepes foka a 23,7\%-át jellemezte. A személyes hatékonyság súlyos csökkenése 27,7\%-nál, közepes mértékú csökkenése 20,0\%-nál jelent meg.

Mészáros és mtsai [19] Budapesten tevékenykedő egészségügyi szakdolgozók reprezentatív mintáján (n = 1333 ) végzett vizsgálatának eredményeit illetően csak a személyes hatékonyság csökkenésére nézve közöltek gyakorisági adatokat. Eszerint a személyes hatékonyság súlyos csökkenését a válaszadók 49,7\%-a, közepes mértékú csökkenését pedig a résztvevők 23,3\%-a mutatta.

Ádám és mtsai [20] ugyancsak a fóvárosban, egészségügyi szakdolgozók körében $(\mathrm{n}=1713)$ végzett vizsgálatuk során azt találták, hogy az érzelmi kimerültség magas foka a válaszadók 20,3\%-át, közepes foka pedig 21,1\%-át érintette. Az elszemélytelenedés mértéke a válaszadók 15,4\%-ánál magas, 17,7\%-ánál közepes volt. A személyes hatékonyság élménye a válaszadók 44,3\%-ánál súlyosan, 22,3\%-ánál pedig közepes mértékben csökkent.

Bencés [21] vizsgálatát a budapesti MÁV Kórház és Központi Rendelőintézet fekvőbeteg-osztályain aktívan dolgozó ápolók körében végezte el $(\mathrm{n}=167)$. A résztvevók $84 \%$-a a súlyosan, 14\%-a pedig a mérsékelten kiégett kategóriába tartozott.

Szemlédy [22] az EuroCare Rt. hálózatán belül, a Magyarország különböző területein dolgozó dializáló ápolók $(\mathrm{n}=109)$, valamint a Pest Megyei Flór Ferenc Kórház ápolói, illetve végzős egyetemi ápolóhallgatói (n = 57) körében végzett vizsgálatot. A magas fokú érzelmi kimerültség a dializáló ápolók 22,4\%-a, míg a többi ápoló 31,3\%-a esetében jelent meg. A kiégettség előfor- 
dulási gyakorisága a dializáló ápolók körében 20\%, míg a többi ápoló körében 37\% volt.

Köbli és mtsai [23] vizsgálatában a Vas Megyei Markusovszky Kórház és a Zala Megyei Szent Rafael Kórház különféle osztályain dolgozó ápolók vettek részt ( $\mathrm{n}=$ 68). Az érzelmi kimerültség 36,8\%-nál magas, 38,2\%-nál közepes fokú volt. Az elszemélytelenedés 23,5\%-nál magasnak, 27,9\%-nál közepes mértékűnek bizonyult. A személyes hatékonyság érzése a résztvevők $41,2 \%$-ánál súlyos, 36,8\%-ánál pedig közepes mértékben csökkent.

Pálfi és mtsai [11] vizsgálatukba egy egyetemi város kórházaiban és klinikáin, különböző ellátási típusú osztályokon dolgozó ápolókat, továbbá a Pécsi Tudományegyetem Egészségtudományi Karán fóiskolai tanulmányaikat folytató, de fóállásban aktívan dolgozó ápolókat vontak be $(\mathrm{n}=481)$. A burnout szindróma különféle intenzitású fokozatai tekintetében a résztvevők 26,0\%-a esetében vannak dolgok, amikre oda kell figyelni, 30,4\%uk kifejezetten veszélyben van a kiégésre, 11,0\%-uk a kiégettség állapotában van, 0,4\%-uk pedig gyógyításra szorul emiatt. A válaszadóknak alig egyharmadáról $(32,2 \%)$ lehetett csak elmondani, hogy a kiégés tekintetében „egészen jól van”.

Pálfi [17] egy másik vizsgálatába Pécs egyetemi város kórházaiban, klinikáin és szociális intézményeiben dolgozó ápolókat vont be $(\mathrm{n}=805 ; 46,5 \%$ intenzív, 34,3\% krónikus, 19,2\% aktív ellátási formájú osztályon múködik). A burnout (kiégési) szindróma különféle intenzitású fokozatainak előfordulási gyakorisága a következő volt: a résztvevők 30,3\%-a esetében vannak dolgok, amikre oda kell figyelni, 33,9\%-uk veszélyben van a kiégés tekintetében, 5,5\%-uk a kiégettség állapotában van, 0,9\%-uk pedig gyógyításra szorul. A válaszadók 29,4\%áról lehetett csak elmondani, hogy a kiégés tekintetében „egészen jól van”. A kiégettség állapotában lévook és a gyógyításra szorulók együttes aránya az intenzív osztályon dolgozók körében volt a legmagasabb (10,7\%), míg ugyanezen arány a krónikus osztályokon 3,6\%, az aktív osztályokon pedig $0,6 \%$ volt.

Nagy [10] a Szabolcs Szatmár Bereg Megyei Kórházak és Egyetemi Oktatókórház aktív és krónikus ellátású osztályain és a Nyíregyháza-Városi Református Egyházközség Sóstói Szivárvány Idősek Otthonában dolgozó ápolókkal végzett vizsgálatot $(\mathrm{n}=130 ; 38,5 \%$ aktív osztályon, 33,1\% krónikus osztályon, 28,5\% idősotthonban dolgozik). A magas fokú érzelmi kimerülés és elszemélytelenedés a minta 20-20\%-át érintette, a személyes hatékonyság súlyos fokú csökkenése pedig a válaszadók 40\%át jellemezte. A krónikus osztályon dolgozó ápolók körében gyakoribb volt a kiégés.

A hazánkban folytatott vizsgálatok eredményei szerint az ápolók körében gyakoriak többek között a fájdalomszindrómák [9, 10], az egészségkárosító magatartásformák [10] és a depresszió [19, 20, 24]. Mindezen problémák szervesen összekapcsolódnak a kiégési szindróma kialakulásának folyamatával.
Az egészségügyi ellátórendszerben dolgozók kiégése nem az érintettek „magánügye”, mert befolyásolja a mühibák és a szövődmények előfordulási gyakoriságát [14]. Az ápolók kiégésének következményei pedig a társadalomra és a gazdasági rendszerre nézve is súlyosak [25]. Igen magas a fluktuáció és a pályaelhagyók aránya $[6,9]$. Egy hazai vizsgálatban a megkérdezett ápolók 37\%-a gondolt már a pályamódosításra, 7\%-uk pedig biztosan váltani akar [21]. Egy frissebb hazai kutatásban részt vevő ápolók 33\%-a gondolt már arra, hogy pályát változtat. A krónikus osztályon volt a leggyakoribb a pályaelhagyás gondolata (46\%), míg az aktív osztályon és az idősotthonban dolgozók körében hasonló arányban fordult elő (28\% és 24\%) [10]. Pályaelhagyás esetében a pályát elhagyó egyének elvesztegetik a képzettségüket, a kórházak elveszítik a képzett és elkötelezett ápolóikat, a betegek számára pedig elvész a minőségi ellátás lehetősége [17], ráadásul az ápolók utánpótlásának költségei az államot terhelik. Éppen ezért az egészségügyi ellátórendszerben megjelenő kiégési szindróma prevenciója, felismerése és kezelése össztársadalmi érdek.

\section{A pszichológiai tanácsadás szerepe az ápolók kiégésének megelőzésében}

A kiégés prevenciója és kezelése kapcsán az első lépés annak feltárása, hogy mely tényezők felelősek elsősorban a tünetcsoport kialakulásáért az adott foglalkozási csoportban. Így a kutatásoknak fontos szerepük van abban, hogy elősegítsék a megfelelő módszerek, megoldások, stratégiák kialakítását. A nemzetközi és hazai kutatások az elmúlt 40 évben számos ismeretet halmoztak fel mind a személyiségben rejlő hajlamosító tényezőkről, mind a szervezet, illetve az intézmények szintjén megragadható, a kiégéssel kapcsolatba hozható tényezőkről (áttekintésként lásd [1, 15, 26]). Ezen bizonyítékok egyszerre segítik, ugyanakkor a sokrétűségük mentén talán kissé nehezítik a kiégés megelőzését és kezelését célzó átfogó stratégia kidolgozását.

Korábban említettük, hogy a kiégést napjainkban az elkötelezettség inverzeként képzelik el, ennek alapján a munka iránti elkötelezettség és a reziliencia elősegítése kerül fókuszba a megelőzés során [2, 27]. A gyengeségek korrekciója helyett a kompetenciák kialakítása, a készségfejlesztés és a teamek facilitálása mentén próbálják fejleszteni a munkavállalók egészségét. Ugyanakkor a jelen pillanatban sem hazánkban, sem pedig a nemzetközi színtéren nincs konszenzus a kiégés kezelésére vonatkozóan. A hatékonyságvizsgálatok kapcsán pedig azt tapasztaljuk, hogy egyelőre kevés a randomizált, kontrollált, többtényezős, hosszú utánkövetéssel bíró vizsgálat $[3,27,28]$.

A kiégést előidéző problémák megelőzése mindazon szinteken lehetséges, amelyeken ezek keletkeznek, azaz egyéni, szakmai, munkahelyi, társadalmi és egészségpolitikai szinten egyaránt $[3,8,28]$. Hangsúlyozandó, hogy a kiégési szindróma kialakulásának folyamata bármikor 
megállítható és visszafordítható [4]. Szerencsére a hazai szakirodalomban is gyakorta találkozhatunk a prevenciót szolgáló konkrét javaslatokkal [11, 17, 21, 28]. A következőkben áttekintjük, hogy az egyéni, szakmai és környezeti/szervezeti szinteken belül hogyan segítheti a kiégési szindróma prevencióját a rendszerben dolgozó pszichológus (tanácsadó, munka- és szervezet-, egészségfejlesztő, illetve alkalmazott egészség-szakpszichológus) illetve mentálhigiénés szakember.

$\mathrm{Az}$ egyénre fókuszáló prevenciónak van a legszélesebb körű hagyománya és irodalma, ugyanakkor meg kell jegyeznünk, hogy ezzel olyan üzenetet közvetíthetünk az ápolók felé, miszerint az ő felelősségük, hibás múködésük, hiányosságuk, nem megfelelő stresszkezelésük következménye a kiégés. Ez koránt sincs így!

Elsőként a hivatásválasztás motivációja kerülhet a fókuszba, amit már a pályaválasztás során érdemes tisztázni, és fontos, hogy a tanulmányi idő alatt az önismeretet nyújtó kurzusok kitérjenek erre. Ebben a felsőoktatásnak van felelőssége. A végzést követően a pályán való elhelyezkedés első éveiben fokozott figyelmet érdemes szentelni az irreális pályakép, irreális elvárások feltérképezésére és realizálására, majd a pályán időnként megállni és megkérdezni, hogy hol tartok most, mi tart itt engem, hogyan változik a motivációm. Ebben a folyamatban hatékonyan tud segíteni a pszichológus. Csabai és Molnár [4] érvelése szerint a segítőszakma választásának hátterében explicit módon általában a segítés motivációja, az emberekkel való foglalkozás öröme áll. Ez természetes elvárás ezeknél a foglalkozásoknál. Csakhogy elképzelhetô, hogy a pályaválasztási szándék hátterében olyan rejtett, fel sem ismert (akár elhárított) motivációk állnak, mint amilyen például a mások kontrollálása vagy a rajtuk való uralkodás. Ha az önismeret növelésének (gyakorta ugyancsak rejtett) vágya áll a pályaválasztás hátterében, akkor a valódi szándék ez esetben sem az, hogy másokon, hanem az, hogy saját magán segítsen az illető. Erre a rejtett motivációra pedig olyan gyógyító szerep épülhet, amely mintegy megalapozza a helfer-szindróma kialakulását. Éppen ezért rendkívül fontos lenne a motiváció feltérképezése már a pályaválasztási tanácsadás során. Az inadekvát motiváció problémája az inadekvát pályaválasztás legalapvetőbb kérdése [29]. Akkor beszélhetünk inadekvát motivációról, amikor meg nem felelést észlelünk a pályaterv és a motivációs bázis között, illetve a valódi motivációk nem tudatosak. Ez a probléma különösen akkor válik égetôvé, ha a pályaválasztás előtt álló fiatal képességei és teljesítménye lehetővé teszik, hogy valóban megszerezze az áhított képesítést. A segítőszakmák esetében azonban a veszélyes, tudattalan motivációk kiélése személyiségtorzuláshoz és ebből következően nemcsak az egyénre, de az általa segített személyekre is káros hatásokhoz vezethet. Ilyen esetekben Herskovits [29] megkerülhetetlennek tartja, hogy a pályaválasztási tanácsadást végző pszichológus önismereti munkát kezdjen a kliensével.
A magas szintü önismeret véd a kiégési szindróma kialakulásával szemben. Különösen fontos a stresszforrások, a saját érzelmi állapot, az esetleges elfogultságok, a „lelki vakfoltok” felismerésének képessége [4]. Az önismeret számtalan módon fejleszthető, egyéni és csoportos formában, verbális és nonverbális módon egyaránt. A csoportos megközelítésre jó példa a hazánkban is széles körben elérhető pszichodráma [30] vagy az alkotómunkában örömet lelők számára a Katarzisz Komplex Múvészetterápia [31]. Ez utóbbi egy többkomponensú, az önismeret növelése mellett egészségvédő, egészségfejlesztő és prevenciós hatású módszer.

A rugalmasság, a nyitottság és a problémaérzékenység is mind olyan személyiségjellemzők, amelyek elősegítik az alternatív helyzetértelmezéseket és ezáltal az adaptív megküzdési stratégiák mozgósítását [4]. A tanácsadás során a kognitív terápiás technikák közül a kognitív újrastrukturálás (átkeretezés) jó szolgálatot tehet ezen diszpozíciók erősítésében. Ezt alátámasztja az a kutatási eredmény, amely szerint a kognitív újrastrukturálás markánsan csökkenti a kiégés és a depressziós tünetek megjelenésének valószínűségét [19]. Mivel a kiégési szindróma előfordulási gyakorisága igen magas a pályakezdők körében, amelyet a valóság megtapasztalása által keltett „sokk” vagy a sikertelen foglalkozási szocializáció következtében fellépő identitáskrízis okoz [32], ugyancsak jótékony hatású, ha a pályakezdők esetében a tanácsadás fókuszába kerül a szakmával kapcsolatos irreális elvárások felismerése és a valósághoz közelebb kerülésüknek a segítése.

A megfelelő mennyiségű és minőségű alvás, illetve pihenés kiemelt jelentőségű a kiégés megelőzésében. Az alváshigiéné javítására vonatkozó egyszerű tanácsok követése - mint például az alvási környezet optimalizálása, a lefekvéshez kapcsolódó szokások kialakítása [33] - elősegíti a 12 órás munkarend és az ügyeletek miatt kialakuló alvásproblémák mérséklését, és ezáltal megelőzi a kifáradást, illetve kimerülést. Mindez azért is jelentős, mert a cirkadián ritmus felborulása miatti alvászavarok nemcsak kimerülést és depressziót okozhatnak, de a gyógyszerezési hibák gyakoriságát is megnövelhetik [34]. Az alváson túlmenően a napi szinten is megjelenő pihenés és a tényleges nyaralás mellett különösen fontos a rendszeres hobbigyakorlás [8]. A tanácsadás során a túlterheltséggel, fáradtsággal küszködő ápolókat segíteni lehetne a prioritások újrarendezésével, a hatékony időgazdálkodási készségek elsajátításával, a nemet mondási készség fejlesztésével, valamint az örömteli, illetve pihentető tevékenységek feltérképezésével és ezeknek a mindennapi életükbe való beillesztésével, például a problémamegoldás stratégiájának alkalmazásával.

A rendszeres fizikai aktivitás nemcsak a testi egészségre gyakorol jótékony hatást, hanem a pszichológiai jóllétre is [35], és az alvás minőségét is javíthatja a cirkadián ritmus beállítását elősegítő („zeitgeber”) hatásával [33]. A sportolás elóírása a tanácsadás során azonban ellenállást válthat ki, mert a rendszeres testedzés számos aka- 
dályba ütközhet. Egy egészségügyi dolgozókkal végzett hazai vizsgálat keretében a résztvevők számára térítésmentesen rendelkezésre bocsátottak egy sportkártyát, amelynek használatával havi 8 alkalommal nyílt lehetőségük sportolásra, méghozzá a résztvevők számára preferált helyszínen és formában. A kedvező feltételek ellenére sokan nem éltek a lehetőséggel, ami a szerzők szerint az idóhiánnyal magyarázható [36]. Az akadályok leküzdésére jelent meg az úgynevezett életmód-aktivitás megközelítés, amelynek lényege a személyek arra való bátorítása, hogy a mindennapjaik során aktívan keressék a lehetőségeket a mozgásra és az energiafelhasználásra, akár még rövid időtartamra is (például séta a következő villamosmegállóig) [37]. Az ilyen jellegú mozgások könnyebben beilleszthetók az ápolók hajszolt, mindennapi életébe, és sikerélményt nyújtanak, ráadásul ezzel a megközelítéssel a nap folyamán nagyobb erőfeszítés nélkül is össze lehet gyújteni a fizikai aktivitás szükséges mennyiségét.

A társas támogatás egészségvédő szerepe jól dokumentált a szakirodalomban [38]. A tanácsadó pszichológus abban segítheti kliensét, hogy feltérképezi a társas hálóját (például a szociális atom technikájának segítségével), és igyekszik tudatosítani a kliensben, hogy kikre támaszkodhat, milyen mennyiségű és minőségü társas támogatásban részesül, mire lenne még szüksége, és az asszertív kommunikáció alkalmazásával hogyan tudná elérni, hogy szükségletei kielégülésre kerüljenek.

Támaszt nyújthatnak, illetve jótékony hatást gyakorolhatnak a stabil hit-és értékrendszerek és a vallásgyakorlás olyan elemei, mint az imádkozás, illetve a meditáció $[8$, 39]. A meditáció feszültségcsökkentő szereppel bír, ezért a tanácsadás során számos egyszerú meditációs gyakorlatot megtaníthatunk (például légzésmeditáció), és akár vallási háttér nélkül is bátoríthatjuk a klienst ezek (lehetőleg mindennapi) alkalmazására. A meditáció ebben a kontextusban a figyelem összpontosítása, ezért számtalan javaslattal élhetünk a mandalakészítéstől [40] kezdve a jógameditáción [41] át a tudatos jelenlét(mindfulness) gyakorlatokig. Ez utóbbiak gazdag tárházát nyújtja az „Én - itt - most - Kreatív mindfulness gyakorlatok" címú, önsegítő kötet [42].

$\mathrm{Az}$ egészség megőrzésében a relaxációs módszerek rendszeres alkalmazása is jelentős szerepet tölt be. Azon túl, hogy a tanácsadás során megtanítjuk a pácienseket relaxálni (például mélylégzéses relaxáció, progresszív izomrelaxáció), figyelmükbe ajánlhatjuk például a hazánkban is elterjedt autogén tréninget. Született egy gyakorlati kézikönyv is, amely kifejezetten az egészségügyi ellátórendszerben dolgozó szakemberek számára mutat be relaxációs technikákat [43].

Egy tíz tanulmányt áttekintő vizsgálatba az ápolók munkahelyi stresszcsökkentésére fókuszáló kutatásokat vontak be. A szerzők arra a megállapításra jutottak, hogy a stresszforrások sokszínúsége, multidimenzionális természete miatt nem valószínű, hogy egyetlen megközelítés hozna eredményeket az ápolók stressz-szintjének csökkentésében [44]. Éppen ezért az egyes stresszkezelö technikák izolált alkalmazása mellett megfontolandó az összetett stresszkezelő programokon való részvétel. Guseo és Hertelendi [39] a stresszkontrolltanfolyam kórházi dolgozók részére történő bevezetésével jó tapasztalatot szereztek, és javasolják, hogy a stresszmendzsment kórházi szinten kötelező jelleggel jelenjen meg, illetve klubok formájában történhessen meg az elsajátított technikák gyakorlása. Jó alternatíva lehet a hazánkban is elérhető Williams ÉletKészségek ${ }^{\odot}$ stresszkezelő és pszichoszociális készségfejlesztő program, amely tíz készség elsajátítása révén ad lehetőséget a mindennapi élet során megjelenő pszichoszociális stressz adekvát kezelésére és az interperszonális kapcsolatok fejlesztésére [45].

Végül, de nem utolsósorban az üzemorvosi vizsgálatokon és a szürövizsgálatokon való rendszeres részvétel elősegíti, hogy már a korai, könnyebben kezelhető szakaszban felismerésre kerüljön a kiégési szindróma, és a szakemberek megtehessék a szükséges lépéseket [8]. Az évenkénti szürővizsgálatokon pszichológiai tesztek segítségével feltérképezhető lenne az ápolók mentális állapota, pszichoszomatikus statusa, valamint adott esetben a formálódó kiégésük mértéke [39].

A következő szint, amelyen a pszichológus lépéseket tehet a kiégés megelőzésében, a szakmai, hivatásbeli kérdések szintje. Györffy és mtsai [8] a nehéz helyzetek kezelésének megkönnyítését szolgáló kommunikációs készségek elsajátítását és hatékony gyakorlását tartják kiemelten fontosnak. Érvelésük szerint érdemes előre átgondolt, ugyanakkor az adott helyzethez rugalmasan alakítható sémákat alkalmazni a sürgősségi helyzetekben. Az ápolás speciális területén elérhető egy kiváló könyv, amely nemcsak az ápoló és a beteg közötti, hanem a munkatársak közötti hatékony, asszertív kommunikáció elsajátítását is segíti [46]. A pszichológusok is hatékony segítséget tudnak nyújtani, az ápolói hivatásra specifikus helyzetekre vonatkozó adekvát kommunikációs készségek fejlesztésében. ${ }^{1} \mathrm{Az}$ ápolószemélyzet számára hasznos lehet a specifikus magatartástréning is, amely elsősorban az ápolási feladatokra irányul, mert növeli a munkaelégedettséget, és csökkenti a stresszt, illetve a megbetegedések számát [47]. Továbbá, mivel egyes felmérések szerint az ápolók a munkájuk egyik legjelentősebb stresszforrásának a haldoklók gondozását tartják, érdemes lenne a gyászmunka speciális szakmai ismereteinek elsajátítása, lehetőleg még a képzés során [24]. A Magyar HospicePalliatív Egyesület évtizedek óta számos tanfolyamot szervez, amelyek speciálisan az orvosok, a szakdolgozók, illetve az önkéntesek számára kerülnek kidolgozásra, és többféle tematikát is felölelnek [24]. ${ }^{2} \mathrm{Az}$ ezeken való részvétel olyan elméleti háttérrel, gyakorlati készségekkel és önismereti hozadékkal vértezi fel a résztvevơket, amely

Az alábbi szakmai anyag ugyancsak segítheti a kommunikációs készségek fejlesztését (letöltve: 2017.05.07-én): http://kepzesevolucioja.hu/dmdocume nts/4ap/1_2321_005_101231.pdf

https://hospice.hu/kepzesek 
nagyban segítheti a kiégési szindróma felismerését, prevencióját és kezelését egyaránt. A prae- és perinatalis időszakban átélt veszteségek a gyász komplikált formáját jelenthetik, amely témakör a jelentősége ellenére kevéssé kutatott, és hazánkban is csak az utóbbi másfél évtizedben születtek vonatkozó tanulmányok. Zsák és Hegedüs [48] érvelése szerint szükséges az aktív és naprakész programok kidolgozása és elérhetővé tétele a hivatásukat ezen a területen gyakorló szakemberek képzésének valamennyi szintjén.

A következő szint, amelyről a jelen tanulmány keretei között szeretnénk gondolkodni, a szervezet, az intézmény vagy munkahely szintje. A szakmai stresszforrások kezelése többnyire elképzelhetetlen a munkahely segítsége nélkül [8]. Az európai direktívák szerint pedig egyenesen a munkáltató feladata megvédeni a munkavállalót a fokozott stresszel szemben. Ennek lényegi lépését képezi a stressz kockázatának felmérése, az érintettek meghatározása, a stresszt triggerelő tényezők feltérképezése, az ártalom megelőzését célzó megoldások kidolgozása és a szükséges intézkedések kivitelezése [6]. Az ápolók mentális állapotának monitorozását, az adott munkahelyen jelen lévő pszichoszociális kockázatfelmérést az ott dolgozó pszichológus, illetve mentálhigiénés szakember végezheti el. A munkahely támogató és a kiégési szindrómától védő faktorként múködhet, amennyiben elősegíti a dolgozókban a munkájuk és a hivatásuk fontosságának érzését, megteremti a dolgozók autonómiájának körülményeit, valamint a szakmai fejlődés lehetőségét. Friganović és mtsai [15] a munkával való elégedettség növelése és a kiégés megelőzésének szempontjából az ápolásmenedzsment szerepét emelik ki, hangsúlyozva a döntéshozatalba való bekapcsolódást.

Nagy szerepe lehet az egyénre szabott motivációs tényezők tudatos alkalmazásának is. A megfelelő motivációs technikák hatékony alkalmazásával a siker-, illetve az énhatékonyság élménye kísérheti a feladatmegoldásokat, amely elősegíti a kreativitás és kezdeményezőképesség növekedését a feladatvégzésben. A teljesítmény pozitív megerősítése az elégedettség és büszkeség érzését eredményezi, amely ösztönzőleg hathat a további feladatok megoldására [21].

Az esetmegbeszélések, illetve a teammegbeszélések különösen fontosak, mert nemcsak szakmai szerepük van, hanem a munkahelyen felmerülő kapcsolati problémák megbeszélésére, kezelésére is teret adnak $[4,8]$. Egy randomizált kontrollált vizsgálat eredményei szerint az esetmegbeszélő, valamint a sorstárssegítő csoportok hatékony megoldást kínálnak a stressz és a kiégés csökkentésére [49]. Speciális és rendkívül gyümölcsöző formája a csoportos megbeszéléseknek a Bálint-csoport [50], amelyben a segítők beszélgetésének középpontját kifejezetten a betegekkel, illetve a munkatársakkal kapcsolatos emocionális problémák képezik. A Bálint-csoport alkalmas lehet az érzelmi intelligencia fejlesztésére [39], valamint az érzelmek kifejezését segítő kimutatási szabályok elsajátítására. A Magyarországi Bálint Mihály
Pszichoszomatikus Társaság szervezésében léteznek kifejezetten ápolók számára meghirdetett Bálint-csoportok is. ${ }^{3}$

Fekete [7] rámutat arra, hogy a deillúzió a kiégés minden egyes fázisában lehet „fertőző”, azaz terjedhet akár a segítőszemélyzet tagjai között, akár a segítőktől a kliensek felé, de még fordítva is. Éppen ezért már a kiégés jeleinek korai felismerése esetében a csoportos tanácsadás igen hatékony segítség lehetne nemcsak az egyénnek, hanem a teljes ápolószemélyzetnek. Egyes szerzők ezért nemcsak javasolják, de kötelezővé is tennék a tematikus segítőcsoportok alakítását és az azokon való részvétel biztosítását [4].

A gyakorló pszichológusok közül elsősorban a munkaés szervezetpszichológusoknak nyílik tere arra, hogy elősegítsék a munkahelyi feltételek optimalizálását, a munkahely protektív szerepének kibontakoztatását, illetve a munkatársak közötti kapcsolatok harmonizálását és a minél gördülékenyebb együttmúködést. A nem megfelelő szakértelemmel szervezett egységekben nagyobb a kockázata a munka káros egészségi, lelki és társas következményeinek, ezért érdemes szorgalmazni és szakmailag megtámogatni a menedzsment reformtörekvéseit. Ennek során kiemelten fontos a munkafolyamatok racionalizálása, gazdaságosabbá tétele, illetve humanizálása, valamint a munkakörnyezet pszichoszociális jellemzőinek javítása [9]. Mivel a munkahelyi stresszorokkal való megküzdésben a munkatársak és a felettesek sokkal több segítséget tudnak nyújtani, mint a munkahelyen kívüli környezet tagjaitól érkező támogatás [32], érdemes ennek erősítésére is hangsúlyt helyezni a szervezetfejlesztési törekvések során. A munkatársak közötti elhúzódó, az együttmúködést gátló konfliktusok megoldására pedig esetenként érdemes lehet mediátorok segítségét kérni.

\section{Következtetések}

A hazánkat érintő súlyos nővérhiány hátterében részben e szakma képviselőinek elvándorlása, illetve pályaelhagyása áll. A nővérhiány kialakulásában szerepet játszik a társadalmi megbecsültség alacsony foka és az ebből fakadó alacsony életszínvonal, valamint a hatalmas fizikai és emocionális megterhelés, amely kiégéssel, azaz a teljes testi és lelki kimerüléssel fenyegeti az egészségügyben dolgozó szakembereket. A kiégés depresszióhoz és pszichoszomatikus betegségek kialakulásához vezethet, a teljes kiégettség (burned-out) állapotában pedig a személy munkaképtelenné, illetve önpusztítóvá válhat [8]. A fentiek miatt az egészségügyi szakemberek kiégésének prevenciója és kezelése, valamint a minőségi ellátás biztosítása a társadalmunk egészének érdeke.

A kiégési szindróma évek, évtizedek alatt alakul ki. Folyamatába bármikor és bármely szinten sikerrel be lehet avatkozni. Ebben rendkívül fontos a szakemberek önis-

${ }^{3}$ http://www.balinttarsasag.hu/balint-csoportok/mukodo-balint-csoportok/ 
merete, a saját állapotuk adekvát megítélése és a bátorság segítségért való folyamodáshoz. A pszichológusok sokféle színtéren és formában tudnak hozzájárulni a kiégés megelőzéséhez és kezeléséhez, s ebben a gyakorlati munka mellett a továbbképzés és a szakmai anyagok publikálása is lényegi szerepet tölthet be.

Anyagi támogatás: A közlemény megírása anyagi támogatásban nem részesült.

A szerzők a cikk végleges változatát elolvasták és jóváhagyták.

Érdekeltségek: A szerzők alkalmanként maguk is tartanak Williams ÉletKészségek stresszkezelő és pszichoszociális készségfejlesztő tréninget, önköltséges formában.

\section{Irodalom}

[1] Kovács M. The phenomenon of burnout in view of the Hungarian and international literature. [A kiégés jelensége a kutatási eredmények tükrében.] LAM 2006; 16: 981-987. [Hungarian]

[2] Schaufeli WB, Leiter MP, Maslach C. Burnout: 35 years of research and practice. Career Dev Int. 2009; 14: 204-220.

[3] West CP, Dyrbye LN, Shanafelt TD. Physician burnout: contributors, consequences and solutions. J Intern Med. 2018, 283 : 516-529.

[4] Csabai M, Molnár P. Medical psychology and clinical health psychology. [Orvosi pszichológia és klinikai egészségpszichológia.] Medicina Könyvkiadó, Budapest, 2009. [Hungarian]

[5] Maslach C. What have we learned about burnout and health? Psychol Health 2001; 16: 607-611.

[6] Pálfiné Szabó I. The characteristics of nurses' and caregivers' behaviour in different clinical settings with special attention to burnout syndrome. [Ápolói és gondozói magatartások alakulása különböző ellátási helyzetekben, különös tekintettel a kiégés jelenségére.] Orv Hetil. 2008; 149: 1463-1469. [Hungarian]

[7] Fekete S. Risks of helping professions - Helper syndrome and burnout. [Segítő foglalkozások kockázatai - Helfer-szindróma és Burnout-jelenség.] Psychiatr Hung. 1991; 6: 17-29. [Hungarian]

[8] Győrffy Zs, Ádám Sz, Pilling J. The physical and mental health of physicians. In: Szántó Zs, Susánszky É. (eds.) Medical sociology. [Az orvosok testi és lelki egészségi állapota. In: Szántó Zs, Susánszky É. (szerk.) Orvosi szociológia.] Semmelweis Kiadó, Budapest, 2006; pp. 105-116. [Hungarian]

[9] Pikó B. Behavioral science approach to nursing profession: psychosomatic symptoms - job-related stress - social support. [A nővéri munka magatartás-tudományi vizsgálata: pszichoszomatikus tünetek, munkahelyi stressz, társas támogatás.] LAM 2001; 11: 318-325. [Hungarian]

[10] Nagy I. Study of burnout syndrome among nurses in Nyíregyháza. [A burnout szindróma vizsgálata a nyíregyházi ápolók körében.] Acta Med Soc. 2015; 6: 39-57. [Hungarian]

[11] Pálfi F, Vranesicsé Horváth I, Németh K, et al. Mental health status of nurses, and risk factors triggering burnout. [Az ápolók mentálhigiénés állapota, és a kiégés szindrómát provokáló faktorok előfordulása a vizsgált populációban.] Nővér 2007; 20(4): 3-13. [Hungarian]

[12] Kumar S. Burnout and doctors: prevalence, prevention and intervention. Healthcare 2016; 4: 37.

[13] Maslach C, Leiter MP. New insights into burnout and health care: strategies for improving civility and alleviating burnout. Med Teach. 2017; 39:160-163.
[14] Győrffy Zs. Female physicians in Hungary. [Orvosnők Magyarországon.] Semmelweis Kiadó, Budapest, 2015. [Hungarian]

[15] Friganović A, Kovačević I, Ilić B, et al. Healthy settings in hospital - how to prevent burnout syndrome in nurses: literature review. Acta Clin Croat. 2017; 56: 292-298.

[16] Irinyi T, Németh A, Lampek K. The relationship of mental health status, violent acts and workplace conflicts among health care providers. [Az egészségügyi szakdolgozók kiégettségének összefüggése az egészségügyi ellátás során kialakuló agressziós cselekmények gyakoriságával és a munkahelyi konfliktussal.] Mentálhig Pszichoszomat. 2018; 19: 205-219. [Hungarian]

[17] Pálfi F. Employ or profession? Risks of burnout among nurses. [Szolgálat, önfeláldozás, hivatás? A kiégés veszélyei ápolók körében.] Nővér 2003; 16(6): 3-9. [Hungarian]

[18] Kovács M, Hegedűs K. Emotion work, emotional dissonance and burnout among health professionals. [Érzelmi munka, érzelmi disszonancia és a kiégés összefüggései az egészségügyi dolgozók körében.] Nővér 2009; 22(5): 3-11. [Hungarian]

[19] Mészáros V, Cserháti Z, Oláh A, et al. Coping with work-related stress in health care professionals - strategies for prevention of burnout and depression. [A munkahelyi stresszel való megküzdés egészségügyi szakdolgozók körében - lehetőségek a kiégés és depresszió megelőzésének szolgálatában.] Orv Hetil. 2013; 154: 449-454. [Hungarian]

[20] Ádám S, Nistor A, Nistor K, et al. Facilitating the diagnosis of depression and burnout by identifying demographic and workrelated risk and protective factors among nurses. [A kiégés és a depresszió diagnosztizálásának elősegítése demográfiai és munkahelyi védő- és kockázati tényezőik feltárásával egészségügyi szakdolgozók körében.] Orv Hetil. 2015; 156: 1288-1297. [Hungarian]

[21] Bencés I. Nurses and burnout. [Az ápolók és a kiégés.] Nővér 2006; 19(3): 10-16. [Hungarian]

[22] Szemlédy I. Study of burnout among dialyzing nurses. [A kiégés jelenségének vizsgálata dializáló ápolók körében.] Nővér 2004; 17(3): 10-20. [Hungarian]

[23] Köbli M, Nagy L, Pálfiné Szabó I. Study of burnout syndrome among nurses. [Kiégés szindróma vizsgálata az ápolók körében.] Nővér 2008; 21(6): 11-20. [Hungarian]

[24] Hegedús K, Riskó Á, Mészáros E. Physical and psychological condition of health care workers dealing with the seriously ill. [A súlyos betegekkel foglalkozó egészségügyi dolgozók testi és lelkiállapota.] LAM 2004; 14: 786-793. [Hungarian]

[25] Némethné Németh E. The burn-out syndrome among nurses of Markusovszky Hospital in Vas county. [A kiégés szindróma a Vas Megyei Markusovszky Kórház ápolói körében.] Nővér 2001; 14(4): 21-24. [Hungarian]

[26] Stevanin S, Palese A, Bressan V, et al. Workplace-related generational characteristics of nurses: a mixed-method systematic review. J Adv Nurs. 2018; 74: 1245-1263.

[27] Back AL, Steinhauser KE, Kamal AH, et al. Building resilience for palliative care clinicians: an approach to burnout prevention based on individual skills and workplace factors. J Pain Symptom Manage. 2016; 52: 284-291.

[28] Szényei GA, Ádám Sz, Győrffy Zs, et al. Prevention of burnout syndrome. From the traditions to the modern information technologies. [A kiégési szindróma megelőzése. A hagyományoktól a modern információs technológiákig.] Magy Pszichol Szle. 2015; 70: 847-862. [Hungarian]

[29] Herskovits M. Possibilities and responsibility of vocational guidance in case of inadequate career objectives. In: Ritoókné Ádám M. (ed.) Psychology of counseling. [A pályaválasztási tanácsadás lehetôségei és felelőssége inadekvát pályaválasztási tervek esetében. In: Ritoókné Ádám M. (szerk.) A tanácsadás pszichológiája.] Nemzeti Tankönyvkiadó, Budapest, 1998; pp. 195-198. [Hungarian] 
[30] Erdélyi I. Theatre of the soul. Psychodrama and the ways of selfknowledge. [A lélek színháza. A pszichodráma és az önismeret útjai.] L'Harmattan Könyvkiadó, Budapest, 2015. [Hungarian]

[31] Antalfai M. Creation and unfolding - Theory and practice of the Katarzisz Complex Art Therapy. [Alkotás és kibontakozás - A Katarzisz Komplex Múvészetterápia elmélete és gyakorlata.] Lélekben Otthon Közhasznú Alapítvány, Budapest, 2016. [Hungarian]

[32] Spooner-Lane RS, Patton WA. Determinants of burnout among public hospital nurses. Aust J Adv Nurs. 2007; 25: 8-16.

[33] Purebl Gy. Low intesity psychological interventions in everyday medical practice. [Alacsony intenzitású pszichológiai intervenciók a mindennapi orvosi gyakorlatban.] Oriold és Társai Kiadó, Budapest, 2018. [Hungarian]

[34] Saleh AM, Awadalla NJ, El-masri YM, et al. Impacts of nurses' circadian rhythm sleep disorders, fatigue, and depression on medication administration errors. Egypt J Chest Dis Tuberc. 2014; 63: 145-153

[35] Clow A, Edmunds S. (eds.) Physical activity and mental health. Human Kinetics, Leeds, 2014.

[36] Terebessy A, Matyasovszky M, Horváth F, et al. The role of physical activity in health promotion of healthcare workers. [A testmozgás szerepe az egészségügyi dolgozók egészségfejlesztésében.] Orv Hetil. 2016; 157: 1563-1570. [Hungarian]

[37] Dunn AL, Marcus BH, Kampert JB, et al. Comparison of lifestyle and structured interventions to increase physical activity and cardiorespiratory fitness. A randomized trial. JAMA 1999; 281: 327-334.

[38] Kállai J. Health and social support. In: Kállai J, Varga J, Oláh A (eds.) Health psychology in practice. [Egészség és társas támogatás. In: Kállai J, Varga J, Oláh A. (szerk.) Egészségpszichológia a gyakorlatban.] Medicina Könyvkiadó, Budapest, 2007; pp. 199216. [Hungarian]

[39] Guseo A, Hertelendi A. Let's save our nurses and doctors! [Mentsünk meg nővéreinket, orvosainkat!] Orv Hetil. 2014; 155: 2082-2092. [Hungarian]

[40] Fincher SF. Creating mandalas. For insight, healing, and selfexpression. [Mandalakészítés. Intuíció, önkifejezés, gyógyulás.] Édesvíz Kiadó, Budapest, 1998. [Hungarian]

[41] Dahlke R. Inner journey. Guided meditations on the inner way. [Belső utazás. Vezetett meditációk a belső úton.] Bioenergetic Kiadó, Budapest, 2017. [Hungarian]
[42] Frey A, Totton A. I am here now: a creative mindfulness guide and journal. [Én - Itt - Most - Kreatív mindfulness gyakorlatok.] Jaffa Kiadó, Budapest, 2016. [Hungarian]

[43] Payne RA. Relaxation techniques: a practical handbook for the health care professional. 2nd edition. Churchill Livingstone, Edinburgh, New York, 1995.

[44] Mimura C, Griffiths P. The effectiveness of current approaches to workplace stress management in the nursing profession: an evidence based literature review. Occup Environ Med. 2003; 60: $10-15$.

[45] Stauder A, Balog P, Kovács M, et al. The Hungarian adaptation of the Williams LifeSkills ${ }^{\circledast}$ stress management and psychosocial skills training program and ten years' implementation in Hungary. [A Williams ÉletKészségek ${ }^{\circledR}$ stresszkezelő és pszichoszociális készségfejlesztő program magyar adaptációja és 10 éves tapasztalatai.] Mentálhig Pszichoszomat. 2016; 17: 81-95. [Hungarian]

[46] Smith S. Communications in nursing. Communicating assertively and responsibly in nursing: a guidebook. [Kommunikáció az ápolásban. Vezérfonal az ápoló önérvényesítő és felelősségteljes kommunikációjához.] Medicina Könyvkiadó, Budapest, 2009. [Hungarian]

[47] Edwards D, Burnard P. A systematic review of stress and stress management interventions for mental health nurses. J Adv Nurs. 2003; 42: 169-200.

[48] Zsák É, Hegedús K. Experiences of loss, grief, coping strategies in pre- and perinatal care. [Veszteségélmények, gyász, megküzdési stratégiák a prae- és perinatalis ellátásban.] LAM 2017; 27: 93-100. [Hungarian]

[49] Peterson U, Bergström G, Samuelsson M, et al. Reflecting peersupport groups in the prevention of stress and burnout: randomized controlled trial. J Adv Nurs. 2008; 63: 506-516.

[50] Harmathy É. What is going on the Balint group? [Mi is történik a Bálint-csoportban (és mi nem)?] Semmelweis Kiadó, Budapest, 2015. Available from: http://magtud.semmelweis.hu/files/ Harmathy_Eva_konyve_Balint.pdf [accessed: May 7, 2017]. [Hungarian]

(Czeglédi Edit dr., Budapest, Üllői út 26., 1085 e-mail: edit.czegledi@gmail.com)

\section{"Iniustus, qui sola putat proba quae facit ipse." (Nincs igazad, ha szerinted csak te cselekszel helyesen.)}

A cikk a Creative Commons Attribution 4.0 International License (https://creativecommons.org/licenses/by/4.0/) feltételei szerint publikált Open Access közlemény, melynek szellemében a cikk bármilyen médiumban szabadon felhasználható, megosztható és újraközölhetö, feltéve, hogy az eredeti szerző és a közlés helye, illetve a CC License linkje és az esetlegesen végrehajtott módosítások feltüntetésre kerülnek. (SID_1) 